\title{
Border/scapes. Borderlands and design studies in dialogue
}

edited by Alice Buoli

Politecnico di Milano, Dipartimento di Architettura e Studi Urbani (alice.buoli@mail.polimi.it)

Nel corso degli ultimi decenni, un crescente interesse verso la produzione culturale sui territori di frontiera si è diffuso parallelamente alla moltiplicazione globale delle frontiere politiche stesse. L'emergere di nuovi approcci culturali e teorici in questo senso, ha aperto prospettive inedite riguardo ai processi di mutua 'costruzione' tra confini politici, (nuove) geografie e strutture del potere, comunità locali/transnazionali. La nozione di borderscapes, nel suo potenziale immaginativo e contro-egemonico, è emersa recentemente come concetto operativo transdisciplinare capace di mettere in relazione diversi campi del sapere. Questo servizio intende contribuire al dialogo tra studi di frontiera e discipline del progetto, presentando una selezione critica di esperienze di ricerca e pratiche progettuali in luoghi di frontiera, sia all'interno sia al di fuori del contesto Europeo

Parole chiave: borderscapes; borderlands design; dialogo interdisciplinare
All over the years 2000s, post-9/11 securitization discourses and the resulting re-affirmation of political borders into a renewed global geography of in/exclusion (Cruz, 2004, p. 1) have deeply influenced the study of borders and borderlands in their mutual social, economic and spatial interweaving.

The intensification and multiplication of international migrations fluxes, transnational and transbordering processes (Irazábal, 2014) have produced a series of new transcalar topographies of knowledge with different outcomes, both in academic urban studies and in professional design ${ }^{1}$ practices.

In a recent publication, A companion to Border Studies, Wilson and Donnan (2012) stressed the «increasing prominence of borders in the lives of many people in all parts of the world» in consideration that «there are more international borders in the world today than ever there were before» (Wilson and Donnan, 2012, pp. 1-2; Boddington, 1999, p. 4; Irazábal, 2014, p. 1).

In this framework, some lines of research have assumed particular relevance in relation to spatial disciplines. For instance, the identification of borders as «social constructs and processes rather than stable entities» (Paasi, 2005, p. 19) that are «socially produced and reproduced, and thus are always susceptible to be modified, transformed, erased, recreated, reimagined, transgressed» (Soja, 2005, p. 34).

Furthermore a conceptual shift occurred in different disciplinary fields in the last years: from a conception of borders as geographical and political peripheries and national 'edge-lands' to another one recognizing them as 'new centres', 'new begging' (Wilson and Donnan, 2012, pp. 3, 13; Eker and Van Houtum, 2013) and «spatial points of origin» (Schoonderbeek in this pages).

The growing international and cross-disciplinary interest towards new conceptualizations and approaches to borders, such as the borderscapes notion (Strüver, 2005; Rajaram and Grundy-War, 2007; Brambilla and van Houtum, 2012), have opened innovative understandings of the mutual 'shaping' processes between political borders, (supra)national power relations and structures, transnational socio-spatial practices and networks and everyday «border struggles» (Mezzadra and Neilson, 2013). By exploring the borderscapes notion as a guiding concept in its different meanings, through the work of scholars, architects and planners practicing on/across borderlands, and envisioning the border in its «constant state of becoming» (Brambilla, 2014, p. 4), this Theme for Territorio intends to contribute to a reciprocal dialogue between borderlands studies and design studies. Though not exhaustive of the broad production on borders and borderlands design, the dos- 
sier aims to clarify how border studies can be relevant for design disciplines, and, to what extent the borderscapes perspective can open new spaces of debate and produce original contributions and discourses about landscape design and planning.

Some open questions, then, are crucial to this dialogue: how can borderlands be re-designed? Which conceptualizations, methods and practices are needed? How to integrate the counter-hegemonic and imaginative potential of the borderscapes notion within a long-term perspective on «new borderlands design» (Eker and Van Houtum, 2013, p. 180) practices? So as to address and test the opportunities behind and beyond these issues, this Theme presents four contributions based on recent on-going research and design experiences in different borderlands, both inside and across the European borders, from a critical and imaginative perspective. The introductory article by the editor, sets the research background on which the Theme is based, by linking a series of conceptual, theoretical and design approaches to borders from different disciplinary fields.

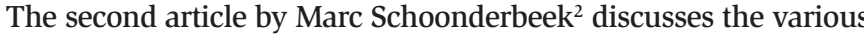
possible border conceptualizations in architectural discourses, by exploring the basic traits of borders in spatial terms and by analysing a full range of contemporary border conditions. By addressing different spatial understandings of the border (as limit, as territorial space, as political place, as space of encounter) Schoonderbeek draws a line of thinking concluding into an interpretation of the border as a space of simultaneity, «a threshold space where spatial practices simultaneously confirm and resist social networks, juridical practices and political ideologies» (Schoonderbeek, in his essay). The third contribution by Henk van Houtum ${ }^{3}$ and Mark Eker explores a new design for cross-borderscapes, by presenting a recent design-oriented research on the Dutch-Belgian-German borderlands, from a scenario-building perspective. The authors, by considering the border as a 'social design' process, argue that border landscapes can be re-imagined and re-designed from a cooperative perspective, with meaningful implications for European Union (EU) cross-border policies.

The fourth paper by Anna Grichting ${ }^{5}$ presents the on-going experience of the Cyprus GreenLineScapes Laboratory by addressing border landscapes as potential ecological reserves and as supports for «a socio-ecological and memory infrastructure» (Grichting, in his essay). By assuming a visioning and future-oriented approach, the paper presents the recent implementation of a platform for collaborative mapping (a Digital and Dynamic Atlas) as a possible tool for Ecological Peace Building in areas of conflict.

Finally a short interview with Pablo de Soto ${ }^{6}$ traces the imaginative outcomes and legacies of Fadaiat and the Observatorio Tecnologico del Estrecho at the Strait of Gibraltar, in the context of the late 90s/early 2000s debate about Europe's external border sealing off dynamics and the peculiar condition of the Spanish-Moroccan borderlands.

Through these five contributions, this Theme aims to explore multiple design-based approaches on borderlands able to develop alternative and committed images, scenarios and tools for rethinking and re-envisioning liminal and contested spaces marked by dynamics of in/exclusion.

\section{Acknowledgements}

This Theme has been developed in the context of the author's doctoral research Border/scaping. Envisioning the Moroccan - Spanish border land- scapes from a territorial design perspective ( $\mathrm{PhD}$ Course in Territorial Government and Design, Dastu, Politecnico di Milano) and has been recently explored in the seminar Border/scaping. Borderlands and urban studies in dialogue, 10 September 2014, Politecnico di Milano. The author is sincerely grateful to Mark Eker, Anna Grichting, Marc Schoonderbeek and Henk van Houtum (authors of this collection) and Pablo de Soto for their inspiring contributions. Thanks to Territorio editorial board, Francesco Infussi and Davide Ponzini for their constant and patient support. Thanks to Matteo Bolocan Goldstein, Paolo Bozzuto, Paola Pucci (Dastu, Politecnico di Milano), Chiara Brambilla (University of Bergamo, Italy), Abel Albet-Mas, Xavier Ferrer-Gallardo, Keina Espiñeira (Universitat Autònoma de Barcelona, Spain) and Nour Eddine Chikhi (Université Abdelmalek Essaâdi, Tetuàn, Morocco) for supporting and orienting the theoretical and empirical research on which this Theme is drawn. Thanks too to the anonymous referees for their accurate and mind-provoking revisions and comments.

\section{Notes}

1. 'Design studies' is here considered in its broad meaning in reference to the disciplines and fields of research concerned with the production of knowledge around a project-oriented perspective, including fields such as architecture, landscape and urban design, spatial planning. The Italian translation term is more correct in this regards as 'discipline del progetto'. 2. Architect founder of 12PM-Architecture (Amsterdam) and coordinator of the research group 'Border Conditions', TU Delft, The Netherlands.

3. Professor and director of the Nijmegen Centre for Border Research, Nijmegen, The Netherlands.

4. Landscape architect and professor at the Technical University of Eindhoven, Eindhoven, The Netherlands.

5. Landscape architect and assistant professor at Qatar University, Doha. 6. Architect, researcher and hacktivist in many fields related to digital culture and innovative forms and narratives for knowledge production and transmission.

\section{References}

Brambilla C., van Houtum, H., 2012, «The Art of Being a 'Grenzgänger': Wandering in the Berlin Borderscapes», Agorà, vol. 28, pp. 28-31.

Brambilla C., 2014. «Exploring the Critical Potential of the Borderscapes Concept». Geopolitics, available at www.tandfonline.com/doi/abs/10.1 080/14650045.2014.884561, last accessed 31/12/2014.

Cruz T., 2004, «Border Postcards: Chronicles from the Edge», James Stirling Memorial Lecture on the City, available at www3.cca.qc.ca/stirling/ download/Cruz_Stirling_Lecture.pdf, last accessed 31/12/2014.

Eker M., Van Houtum H., 2013, Border Land: Atlas, Essays and Design. History and Future of the Border Landscape, Blauwdruk, Wageningen.

Irazábal C., 2014, «Transbordering Planning: Esempi dall'America Latina», Territorio, n. 69, pp. 7-17. Doi:10.3280/TR2014-069001.

Mezzadra S., Neilson B., 2013, Border as Method, or, the Multiplication of Labor, Duke U.P., Durham.

Paasi A., 2005, «The Changing Discourses on Political Boundaries. Mapping the Backgrounds, Contexts and Contents», in Houtum van H., Kramsch O.T., Zierhofer W. (eds.), B/ordering Space, Ashgate, London.

Rajaram P.K., Grundy-Warr C., 2007, «Introduction», in Rajaram P.K., Grundy-Warr C., (eds.), Borderscapes: Hidden Geographies and Politics at Territory's Edge, University of Minnesota Press, Minneapolis.

Soja E., 2005, «Borders Unbound. Globalization, Regionalism, and the Postmetropolitan Transition», in Houtum van H., Kramsch O.T., Zierhofer W. (eds.), B/ordering Space, Ashgate, London, pp. 33-46.

Strüver A., 2005, Stories of the 'Boring Border': The Dutch-German Borderscape in People's Minds, Lit Verlag, Münster.

Wilson T.M., Donnan H., 2012, «Borders and Border Studies», in Wilson T.M., Donnan H. (eds.), A Companion to Border Studies, Wiley-Blackwell. 